\title{
Phytoremediation of mixed-contaminated soil using the hyperaccumulator plant Alyssum lesbiacum: Evidence of histidine as a measure of phytoextractable nickel
}

\author{
Andrew C. Singer ${ }^{\mathrm{a}, *}$, Thomas Bell ${ }^{\mathrm{b}}$, Chloe A. Heywood ${ }^{\mathrm{a}}$, J.A.C. Smith ${ }^{\mathrm{c}}$, Ian P. Thompson ${ }^{\mathrm{a}}$ \\ ${ }^{\text {a }}$ Centre for Ecology \& Hydrology-Oxford, Mansfield Road, Oxford OX1 3SR, UK \\ ${ }^{\mathrm{b}}$ Department of Zoology, University of Oxford, South Parks Road, Oxford OX1 3PS, UK \\ ${ }^{\mathrm{c}}$ Department of Plant Sciences, University of Oxford, South Parks Road, Oxford OXI 3RB, UK
}

Received 30 June 2006; received in revised form 18 August 2006; accepted 20 August 2006

\begin{abstract}
Alyssum lesbiacum was shown to phytoextract nickel from PAH-contaminated soils from which the pool of nickel accessed for phytoextraction is closely modelled by a histidine-soil extract.
\end{abstract}

\begin{abstract}
In this study we examine the effects of polycyclic aromatic hydrocarbons (PAHs) on the ability of the hyperaccumulator plant Alyssum lesbiacum to phytoextract nickel from co-contaminated soil. Planted and unplanted mesocosms containing the contaminated soils were repeatedly amended with sorbitan trioleate, salicylic acid and histidine in various combinations to enhance the degradation of two PAHs (phenanthrene and chrysene) and increase nickel phytoextraction. Plant growth was negatively affected by PAHs; however, there was no significant effect on the phytoextraction of Ni per unit biomass of shoot. Exogenous histidine did not increase nickel phytoextraction, but the histidine-extractable fraction of soil nickel showed a high correlation with phytoextractable nickel. These results indicate that Alyssum lesbiacum might be effective in phytoextracting nickel from marginally PAH-contaminated soils. In addition, we provide evidence for the broader applicability of histidine for quantifying and predicting Ni phytoavailability in soils.
\end{abstract}

(C) 2006 Elsevier Ltd. All rights reserved.

Keywords: Phytoextraction; Phytoremediation; Bioremediation; Nickel; Alyssum lesbiacum; Metal hyperaccumulator; Histidine; Co-contaminated soil

\section{Introduction}

Phytoextraction - the transfer of metal from an aqueous or terrestrial source into plant biomass - is one of the few biological approaches for remediating metal-contaminated soils. Metal phytoextraction may be most effectively carried out by metal-hyperaccumulating plants, which specialise in sequestering high concentrations of metal in their above-ground biomass - a trait shared by relatively few species in the world (Baker and Brooks, 1989; Robinson et al., 1997b). A nickel hyperaccumulator is defined as a plant that concentrates nickel

\footnotetext{
* Corresponding author. Tel.: +44 (0)1865 281 630; fax: +44 (0)1865 281696.

E-mail address: acsi@ceh.ac.uk (A.C. Singer).
}

to at least $1000 \mathrm{mg} \mathrm{Ni} \mathrm{kg}^{-1}$ in its shoot dry biomass (Brooks et al., 1977). Alyssum lesbiacum (Candargy) Rech.f. is among the few Ni hyperaccumulators for which significant progress has been made in detailing the mechanism of metal uptake (Ingle et al., 2005; Kerkeb and Krämer, 2003). In a number of Alyssum species, a strong positive correlation has been found between $\mathrm{Ni}$ exposure and histidine production (Krämer et al., 1996). Ingle et al. (2005) demonstrated that the histidine biosynthetic pathway is constitutively more highly expressed in A. lesbiacum than in the congeneric non-accumulator species A. montanum. The high expression level of histidine biosynthesis genes maintains a large pool of free histidine in the roots, which increases proportionately with $\mathrm{Ni}$ uptake (Ingle et al., 2005). Additional species of Alyssum are currently being investigated for field-scale metal phytoextraction (Angle et al., 
2001; Kukier et al., 2004; Li et al., 2003a; Robinson et al., 2003).

Considerable research has demonstrated the contribution of plants to remediation of soils contaminated with organic chemicals through the 'rhizosphere effect' - the area around the root where there is an increase in microbial biomass and activity (Arthur et al., 2005; Shaw and Burns, 2003). A wealth of studies have also demonstrated the role of bioaugmentation and biodegradation-enhancing chemicals in facilitating organic pollutant degradation in soil (Singer et al., 2005; van Veen et al., 1997). However, few studies have investigated the ability of metal-hyperaccumulating plants to extract metals effectively in mixed-contaminated soils.

In the present study, we examine the effect of biodegradationenhancing chemicals and metal chelators on the phytoextraction of $\mathrm{Ni}$ in a mixed-contaminated soil. In view of the recent interest in the application of Alyssum for metal remediation (Angle et al., 2001; Kukier et al., 2004; Li et al., 2003a,b), A. lesbiacum was assessed for Ni phytoextraction in the presence of two polycyclic aromatic hydrocarbons (PAHs), phenanthrene and chrysene. These PAHs are among the most abundant constituents of organic polluted sites (e.g., coal-gas manufacturing plants: ATSDR, 1995). Among the three amendments investigated, two - sorbitan trioleate (surfactant) and salicylic acid (PAH biodegradative inducer) - were selected for their potential contribution towards PAH biodegradation. Sorbitan trioleate, a surfactant containing three $\mathrm{C}_{16-18}$ aliphatic groups on a sugar backbone, was applied to enhance the bioavailability of the PAHs, as had been previously demonstrated with polychlorinated biphenyls (Singer et al., 2000) and pentachlorophenol (unpublished data). Salicylic acid, a metabolite of and inducer for the naphthalene operon, was investigated as a soil amendment to stimulate indigenous microbial degradation of PAHs (Chen and Aitken, 1999; Singer et al., 2000). Interestingly, salicylic acid is known to be involved in pathogen-induced defence responses in plants and is present at elevated concentrations in metal-hyperaccumulator plants in the genus Thlaspi, where it is implicated in the high degree of cellular tolerance towards nickel (Freeman et al., 2005).

The third amendment, histidine, was selected primarily for its Ni-chelating properties. In lieu of other natural organic-acid chelates such as citrate, oxalate, or acetate (Khodadoust et al., 2004; McGrath and Zhao, 2003), histidine was chosen for its biological compatibility with the presumed mechanism of $\mathrm{Ni}$ sequestration in A. lesbiacum (Krämer et al., 1996). Its selection also lessens concerns associated with the use of EDTA, a toxic and persistent synthetic chelate employed in previous phytoextraction studies (Meers et al., 2004; Vassil et al., 1998). All soils were evaluated from two depths (0 to $5 \mathrm{~cm}$ and 5 to $10 \mathrm{~cm})$ and fractionated into a coarse $(>75 \mu \mathrm{m})$ and fine fraction $(<75 \mu \mathrm{m})$ to further examine the distribution and dynamics of $\mathrm{Ni}$ within the treatments. Each soil fraction was assayed for the water-, histidine- and acid-extractable $\mathrm{Ni}$ pools, representing pools of nickel from which a decreasing percentage of nickel is presumed to be phytoaccessible.

A histidine-utilizing, Ni-tolerant bacterium, which was previously isolated from the experimental soil, was repeatedly amended to a multi-component treatment to facilitate the disruption of the Ni-histidine complex - a potentially rate-limiting step for the phytoextraction of $\mathrm{Ni}$ in A. lesbiacum.

In this study, our aims were: (1) to assess the individual and additive effects of salicylic acid, sorbitan trioleate and histidine amendment on the phytoextraction of Ni and biodegradation of PAHs; (2) to examine the relationship between the water-, histidine- and acid-extractable Ni pools and the phytoextractable $\mathrm{Ni}$ pool; and (3) to examine the performance of A. lesbiacum in co-contaminated (non-serpentine) soil.

\section{Materials and methods}

\subsection{Soil contamination}

Thirty kg of uncontaminated agricultural sandy-loam soil (Table 1: Wick series, sandy loam soil from the Wellesbourne National Vegetable Research Station, Warwickshire, UK (Whitfield, 1974)) was air-dried and sieved ( $2 \mathrm{~mm}$, Mesh No. 10) prior to spiking with Ni and PAHs. Two 10\% (w/w) subsamples of the sandy-loam soil were then spiked with either an acetone solution $(1: 1, \mathrm{v} / \mathrm{w})$ of phenanthrene and chrysene or an acetone-aqueous solution $(1: 1, \mathrm{v} / \mathrm{w})$ of $\mathrm{NiSO}_{4}$. The spiked soil subsamples were mixed with $\mathrm{Ni}, \mathrm{PAH}$, or pristine soil $(1: 1)$ to a final concentration of $100 \mathrm{mg}$ phenanthrene and chrysene $\mathrm{kg}^{-1}$ soil and $50 \mathrm{mg} \mathrm{Ni} \mathrm{kg}^{-1}$ soil as described in Section 2.4. The soil $\mathrm{Ni}$ concentration of $50 \mathrm{mg} \mathrm{kg}^{-1}$ was chosen: (1) to enable detection of small shifts in the soil Ni pools owing to phytoextraction, since a larger initial soil concentration would have masked these subtle shifts; (2) to assess the potential for using A. lesbiacum as a tool to phytoextract metals from marginally contaminated soil; and (3) to evaluate the application of A. lesbiacum at the UK government target for residential sites, $50 \mathrm{mg} \mathrm{Ni} \mathrm{kg}^{-1}$ soil (Environment Agency, 2002). The soil PAH concentration of $100 \mathrm{mg} \mathrm{kg}^{-1}$ was chosen to provide sufficiently realistic levels of PAH to lend insight into the efficacy of nickel phytoextraction in co-contaminated soils, as well as the sub-lethally toxic response of A. lesbiacum to PAHs.

Table 1

Physical and chemical parameters of the experimental soil

\begin{tabular}{|c|c|c|}
\hline & & Mean $\pm \mathrm{SD}(n)$ \\
\hline \multicolumn{3}{|c|}{ Soil chemical parameters } \\
\hline & $\mathrm{CEC}\left(\mathrm{cmol} \mathrm{kg}^{-1}\right)$ & $7.71 \pm 0.31$ \\
\hline & $\mathrm{pH}$ & $5.74 \pm 0.08$ \\
\hline \multicolumn{3}{|c|}{ Soil texture $^{a}$} \\
\hline & $\%$ Soil particles $>75 \mu \mathrm{m}$ & $77 \pm 3(6)$ \\
\hline & $\%$ Soil particles $<75 \mu \mathrm{m}$ & $23 \pm 3(6)$ \\
\hline & $\%$ Sand & $73^{b}$ \\
\hline & $\%$ Silt & $12^{\mathrm{b}}$ \\
\hline & $\%$ Clay & $14^{\mathrm{b}}$ \\
\hline \multicolumn{3}{|c|}{ Clay } \\
\hline & $\%$ Illite & $27.0 \pm 1.7$ \\
\hline & $\%$ Expandable $^{\mathrm{c}}$ & $61.7 \pm 2.5$ \\
\hline & $\%$ Kaolinite & $11.3 \pm 1.2(3)$ \\
\hline \multicolumn{3}{|c|}{ Organic matter } \\
\hline & Loss on ignition (\%) & $2.24 \pm 0.01$ \\
\hline & $\%$ Carbon & $0.67 \pm 0.01$ \\
\hline & $\%$ Nitrogen & $0.08 \pm<0.01$ \\
\hline & Carbon:nitrogen & $8.37 \pm 0.18$ \\
\hline & $\mathrm{kg}^{-1}$ soil) & \\
\hline
\end{tabular}

$$
\mathrm{Ni}
$$$$
24 \pm 2.21(8)
$$

\footnotetext{
a Percent soil texture values were determined on a dry mass basis.

b Whitfield (1974).

c The 'expandable' component in this sample is a random mixed-layer illite/ smectite.
} 
The contaminated soils were mixed by rolling within a closed barrel twice weekly for seven weeks to ensure homogeneous contamination and complete removal of solvent vapours. Approximately $0.280 \mathrm{~kg}$ of spiked soil was amended to each of 88 experimental columns (see Section 2.4), which were constructed of polyvinylchloride (PVC) pipes $(5.08 \mathrm{~cm} \mathrm{I.D.} \times 20 \mathrm{~cm}$ length). Columns were initially filled with pristine soil at the bottom (approx. $3 \mathrm{~cm}$ ) to minimise gas diffusion from beneath the soil profile and to trap leached chemicals, denoted in Fig. 1 as the pristine soil barrier (Singer et al., 2001). The contaminated soil was added to the columns to a depth of $10 \mathrm{~cm}$ $\left(1.43 \mathrm{~g}\right.$ soil $\left.\mathrm{cm}^{-3}\right)$ after the addition of a glass-fibre filter barrier to separate the contaminated and pristine soils.

\subsection{Planted soil column design}

Forty columns were each sown with four A. lesbiacum seeds (obtained from Lesvos, Greece, and kindly provided by A.J.M. Baker) on the soil surface and maintained in a glasshouse with natural solar illumination. The soil columns were irrigated daily ( $\sim 15 \mathrm{~mL}$ tap water) by an automated overhead sprinkler system for the full length of the study (14 weeks from sowing of seeds). Fourteen days after sowing, columns were restocked with seedlings to compensate for poor germination and mortality, ensuring at least two plants within each planted column at this point. The different amendments were then applied and no further transplants were made, so as to minimize disruption to the soil profile. However, this procedure led to some treatments containing replicate columns with fewer than the desired two plants each (Table 2).

\subsection{Bacterial inoculum}

A Ni-tolerant histidine utilizing bacterium was previously isolated from the experimental soil by batch enrichment on $3.22 \mathrm{mM}$ L-histidine and $3.22 \mathrm{mM} \mathrm{NiSO}_{4}$ in minimal salts medium (MSM) (Gilbert and Crowley, 1997) adjusted to $\mathrm{pH} 7.0$ with $\mathrm{NaOH}$. The major species of $\mathrm{Ni}$ in solution, as determined by MINEQL+ (Environmental Research Software, Hallowell,

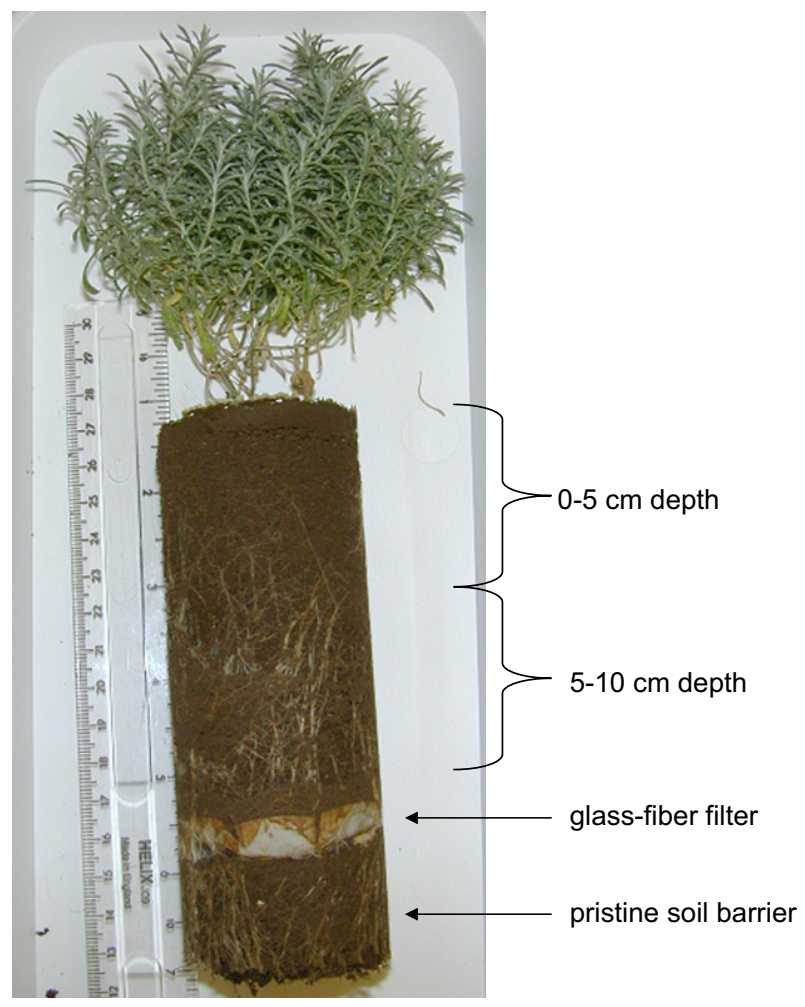

Fig. 1. Alyssum lesbiacum and soil profile after removal from PVC pipe. Evidence of dense rooting zone, particularly in the 5 to $10 \mathrm{~cm}$ depth.

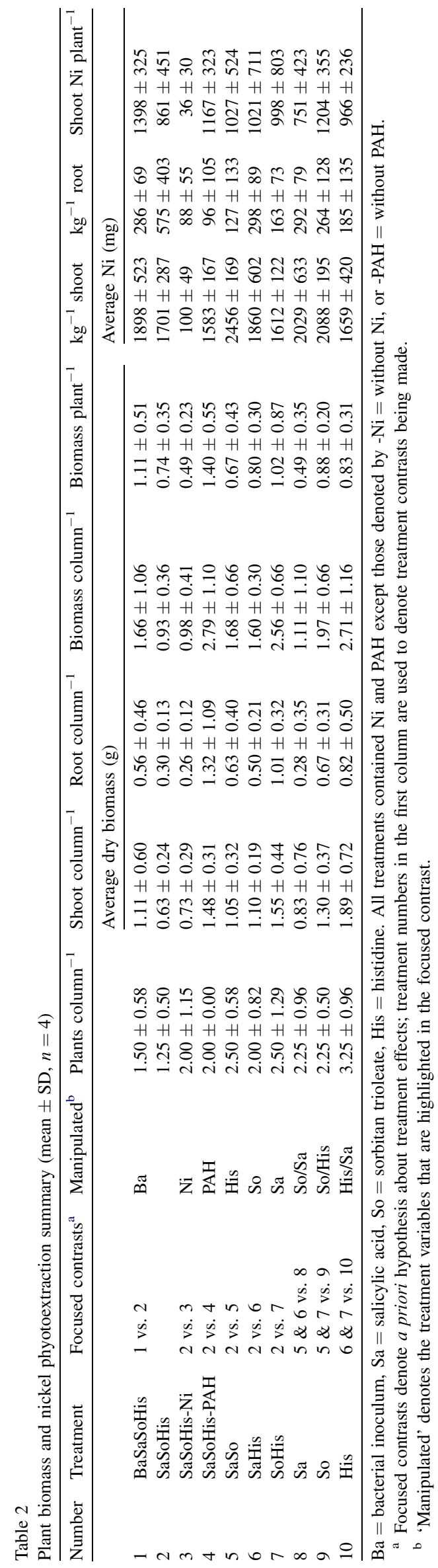


ME, USA: Schecher and McAvoy, 1992) and GEOCHEM-PC, version 2.0 (Parker et al., 1995), were $\mathrm{Ni}(\mathrm{His})$ and $\mathrm{Ni}(\mathrm{His})_{2}$, where $99 \%$ of the histidine was complexed with $\mathrm{Ni}$. The bacterium was selected from other isolates because of its rapid growth. A $398 \mathrm{~kb}$ fragment from the $16 \mathrm{~S}$ rRNA of this isolate gave a 99\% nucleotide sequence identity to Arthrobacter histidinolovorans (data not shown). Previous reports of this bacterium indicate its ability to metabolise histidine as well as convert histidinol to histidine (Adams, 1954). It was hypothesized that repeated addition of this isolate to planted soils would expedite dissociation of the histidine-Ni complex, and possibly increase phytoextraction, if dissociation was necessary for transport of $\mathrm{Ni}$ into the root of A. lesbiacum.

\subsection{Experiment design and analysis}

Four replicates of ten planted and unplanted treatments were amended with one or more of the following treatments, as per Table 2: A. histidinolovorans (Ba), $3.6 \mathrm{mM}$ salicylic acid (Sa), $0.8 \mathrm{mM}$ sorbitan trioleate (So), and $3.22 \mathrm{mM}$ L-histidine (His). Treatments were repeatedly added in $15 \mathrm{~mL}$ aliquots twice weekly. Two additional unplanted treatments were prepared: (1) co-contaminated soil amended with minimal salts medium (MSM); and (2) a pristine soil control (Pristine). A. histidinolovorans was prepared for treatment BaSaSoHis by culturing the bacterium in a $250 \mathrm{~mL}$ Erlenmeyer flask containing $100 \mathrm{~mL}$ of MSM and $3.22 \mathrm{mM}$ His. The culture was combined with $100 \mathrm{~mL}$ of MSM containing 7.2 $\mathrm{mM} \mathrm{Sa}$, and $1.6 \mathrm{mM}$ So prior to addition to the soil, to make a final amendment concentration of $3.6 \mathrm{mM}$ Sa and $0.8 \mathrm{mM}$ So.

\subsection{Sampling and chemical analysis}

The soil columns were dismantled 12 weeks after the first addition of amendments ( 14 weeks from sowing), by carefully separating the 0 to $5 \mathrm{~cm}$ and 5 to $10 \mathrm{~cm}$ depths and pristine soil barrier (Fig. 1). Using an ethanolwashed stainless steel spatula, each depth was mixed thoroughly and dispensed into $40-\mathrm{mL}$ borosilicate vials before being frozen at $-80^{\circ} \mathrm{C}$ and freeze-dried. Each of the four treatment replicates at both depths were sieved (200 mesh, $75 \mu \mathrm{m})$ into a fine and coarse fraction. These sieved soil fractions were then subjected to water-, histidine- and nitric acid extractions as described below.

Water-extractable $\mathrm{Ni}$ analyses were carried out on $1.00 \mathrm{~g}$ soil in $50-\mathrm{mL}$ polypropylene centrifuge tubes containing $9.0 \mathrm{~mL}$ of $0.1 \mathrm{M} \mathrm{MgCl}_{2}$ solution, while histidine-extractable $\mathrm{Ni}$ analyses were carried out similarly in a $3.22 \mathrm{mM}$ L-histidine solution ( $\mathrm{pH}$ 7.0). In both cases, samples were shaken horizontally for $60 \mathrm{~min}$, followed by centrifuging at $3000 \times \mathrm{g}$ for $15 \mathrm{~min}$ $\left(20^{\circ} \mathrm{C}\right)$. The supernatant was passed through a $0.45 \mu \mathrm{m}$ PTFE syringe filter into a $15 \mathrm{~mL}$ polypropylene tube for analysis by atomic absorption spectrophotometry (AAS; wavelength: $232.0 \mathrm{~nm}$, flame gases: air and acetylene, detection limit: $0.02 \mathrm{mg} \mathrm{L}^{-1}$, sensitivity: $0.15 \mathrm{mg} \mathrm{L}^{-1}$, optimum rage: 0.3 to $10 \mathrm{mg} \mathrm{L}^{-1}$ ) using an AAnalyst 100 with deuterium arc background correction (Perkin-Elmer, Beaconsfield, Buckinghamshire, UK). Acid-extractable Ni extractions were carried out on $100 \mathrm{mg}$ soil (dry mass), to which $3 \mathrm{~mL}$ nitric acid $(69 \%, v / v)$ was added. The sample was vortexed for $1 \mathrm{~min}$, and left incubating at $70{ }^{\circ} \mathrm{C}$ for $36 \mathrm{~h}$. After incubation, $4 \mathrm{~mL}$ of deionized water was added to each vial, vortexed, centrifuged at $3000 \times g$ for $15 \mathrm{~min}\left(20^{\circ} \mathrm{C}\right)$ and passed through a $0.45 \mu \mathrm{m}$ PTFE filter for analysis by AAS. The nitric-acid extractable Ni procedure was adopted in lieu of an aqua regia digest, as there was no significant difference in extractable nickel between the two methods for the experimental soil (data not shown).

Phenanthrene and chrysene were extracted from $1.00 \mathrm{~g}$ soil in duplicate from unfractionated soil at each of the depths. The soil was vortexed for $1 \mathrm{~min}$ in $4 \mathrm{~mL}$ dichloromethane:acetone (3:1), followed by a $2 \mathrm{~h}$ incubation in a sonicating bath $\left(34^{\circ} \mathrm{C}\right)$ and agitation for $18 \mathrm{~h}$ on a horizontal shaker. The selection and ratio of PAH extraction solvents were experimentally determined to yield the greatest PAH recovery from the experimental soil (data not shown). Analysis of PAH extractions were performed by gas chromatographymass spectrometry (Perkin-Elmer Autosystem GC-MS), equipped with an Agilent DB- $5 \mathrm{~ms}$ capillary column $(30 \mathrm{~m}$ length $\times 0.25 \mu \mathrm{m}$ film thickness $\times 0.25 \mathrm{~mm}$ ID). A $1 \mu \mathrm{l}$ injection was analysed with the following instrument parameters: injector temperature $280^{\circ} \mathrm{C}$, detector and transfer line $230^{\circ} \mathrm{C}$; He carrier at $17 \mathrm{psi}$ and $40 \mathrm{~mL} \mathrm{m^{-1 }}$ split. The temperature program initiated at $60{ }^{\circ} \mathrm{C}$, held $1 \mathrm{~min}$, ramped $15^{\circ} \mathrm{C} \mathrm{min}^{-1}$ to a final $270{ }^{\circ} \mathrm{C}$, and held $12 \mathrm{~min}$. Quantification was based on single-ion monitoring of biphenyl (internal standard) at $\mathrm{m} / \mathrm{z} 155$, phenanthrene at $\mathrm{m} / \mathrm{z} 178$, and chrysene at $\mathrm{m} / \mathrm{z} 228$.

\subsection{Plant analysis}

Plant roots were carefully removed from the soil, agitated for approximately $1 \mathrm{~min}$ in $10 \mathrm{mM}$ EDTA, blotted dry and weighed. The root and shoot samples were subsequently stored in a paper bag at $-20^{\circ} \mathrm{C}$ until $\mathrm{Ni}$ analysis. Plant material was oven-dried $\left(70^{\circ} \mathrm{C}\right)$, crushed into a powder, and prepared in duplicate for microwave digests by adding $5 \mathrm{~mL}$ of $69 \%(\mathrm{v} / \mathrm{v}) \mathrm{HNO}_{3}$ into an extraction vial containing $250 \mathrm{mg}$ of plant material. Samples were digested in CEM advanced composite pressure vessels using a CEM MDS 2000 microwave digestion system (CEM Microwave Technology, Buckingham, UK) and then analysed by flame AAS as described above.

\subsection{Soil analysis}

Percent carbon and nitrogen was determined in the 5 to $10 \mathrm{~cm}$ depth, in duplicate, using a Europa Roboprep/VG 622 mass spectrometer (Europa Scientific Ltd, Cheshire, UK). Using the reference atropine (4.84\% nitrogen and $70.5 \%$ carbon) and the certified reference GBW 07412, IAEA-309, and LECO standard calcium carbonate for quality control (Table 3). Soil pH was measured using a digital $\mathrm{pH}$ meter from $1.00 \mathrm{~g}$ of soil from both soil depths after vortexing in $0.1 \mathrm{mM} \mathrm{MgCl} 2$ and centrifuging at $3000 \times g$ for $5 \mathrm{~min}$ at $20^{\circ} \mathrm{C}$ (Table 3).

\subsection{Chelating study}

A small study was conducted to quantify the effects of each amendment, singularly and in combination, on $\mathrm{Ni}$ desorption. Triplicate $1.00 \mathrm{~g}$ freshlyspiked experimental soil aliquots containing $200 \mathrm{mg} \mathrm{NiSO}_{4} \mathrm{~kg}^{-1}$ soil were extracted with $15 \mathrm{~mL}$ of a $3.22 \mathrm{mM}$ solution of each of the following amendment combinations in deionised water ( $\mathrm{pH}$ adjusted to 7.0 with $\mathrm{NaOH}$ or $\mathrm{HNO}_{3}$ ): (1) $\mathrm{Ca}\left(\mathrm{NO}_{3}\right)_{2}$; (2) Sa; (3) So; (4) His; (5) SaSoHis; (6) EDTA; and (7) SaSoHisEDTA. Samples were prepared and analysed by AAS as described in Section 2.5 .

\subsection{Statistics}

As the unbalanced experimental design precluded the use of conventional analysis of variance, we chose to conduct focused contrasts of particular amendment combinations (Rosenthal and Rosnow, 1985) based on our a priori hypotheses on how particular amendments would affect the response variables. Significance is presented as a result of these focused contrasts unless otherwise stated. We also used the Tukey HSD test for particular cases when we were interested in comparing all the amendment combinations against each other. Most statistical analyses were conducted using $R$ version 1.9.0, while paired two sample for means $t$-tests were conducted on Microsoft Excel 2002. Unless otherwise specified, statistical significance was at the $P<0.05$ level, while errors $( \pm)$ of presented data are standard deviations.

\section{Results and discussion}

\subsection{Chelating study}

In the chelating study (Fig. 2), we examined the effects of chemical amendments on $\mathrm{Ni}$ desorption in freshly spiked $\mathrm{Ni}$ contaminated soil $\left(200 \mathrm{mg} \mathrm{Ni} \mathrm{kg}{ }^{-1}\right)$. In the control treatment $\left(3.22 \mathrm{mM} \mathrm{Ca}\left(\mathrm{NO}_{3}\right)_{2}\right), 13 \pm 1 \%$ of the total soil $\mathrm{Ni}$ was desorbed. Neither Sa nor So desorbed greater Ni than the control extractant $(P>0.05)$, suggesting a limited role for these amendments in $\mathrm{Ni}$ desorption for this study. Khodadoust 
Table 3

Distribution of nickel by depth and extractant in water-, histidine- and acid-extractable soil, either planted and unplanted (expressed as mg Ni kg ${ }^{-1}$ soil)

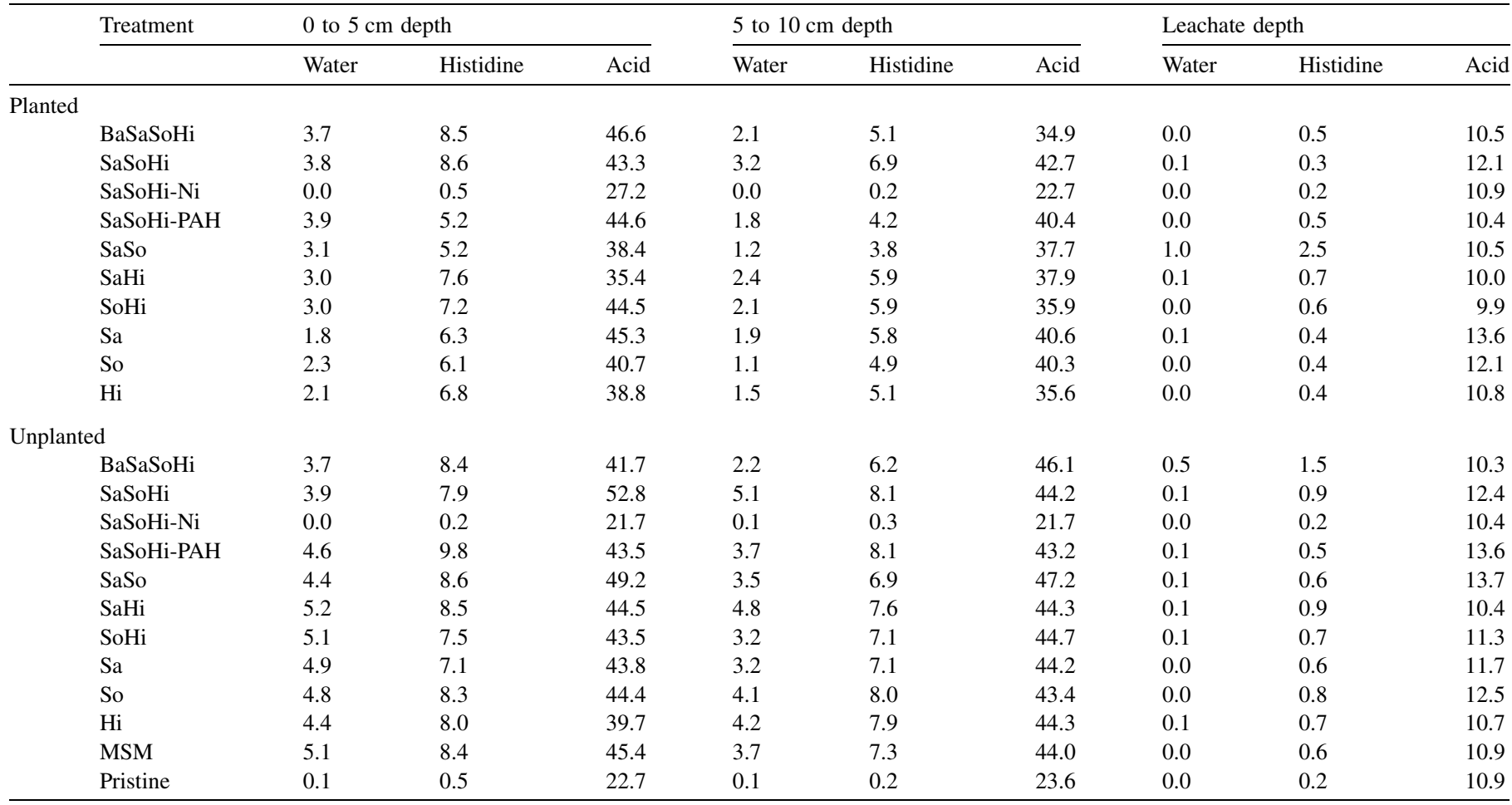

There are $140 \mathrm{~g}$ of soil for each of the two depths 0 to $5 \mathrm{~cm}$ and 5 to $10 \mathrm{~cm}$.

et al. (2004) also found marginal desorption of soil $\mathrm{Ni}$ (10 to $16 \%$ ) using Tween 80 , a $\mathrm{C}_{18}$ sorbitol-based surfactant similar to sorbitan trioleate. In contrast, histidine mobilised nearly $50 \%$ of the soil $\mathrm{Ni}\left(98 \pm 8 \mathrm{mg} \mathrm{Ni} \mathrm{kg}^{-1}\right.$ soil), which was significantly greater than the control $(P=0.006)$ and similar to the EDTA extract, thus confirming the efficacy of histidine as a strong Ni-binding ligand. No significant increase in Ni desorption was achieved with the combined addition of SaSoHis or SaSoHisEDTA as compared to histidine alone (Fig. 2).

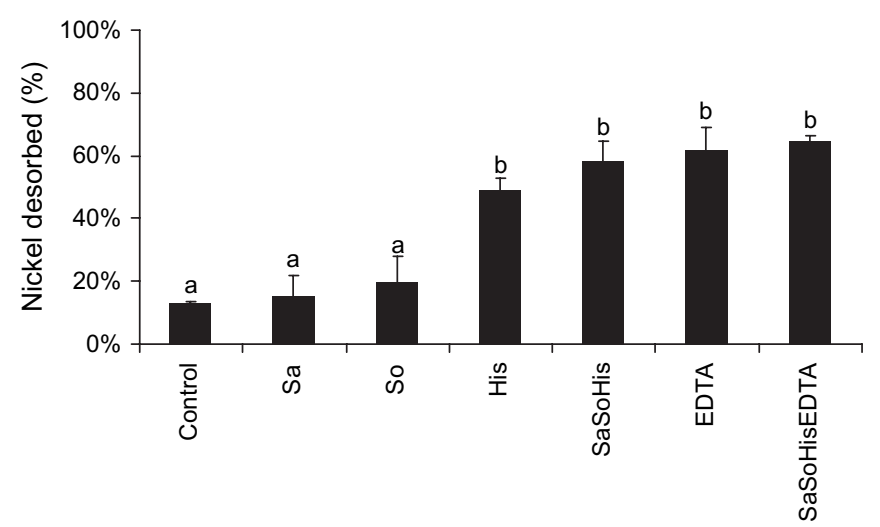

Fig. 2. Nickel desorbed, as a percentage of total nickel spike, with the singular and combined addition of $3.22 \mathrm{mM}$ of the different amendments: salicylic acid (Sa), sorbitan trioleate (So), histidine (His). EDTA was included for comparison. Initial soil nickel spike was $200 \mathrm{mg} \mathrm{kg}^{-1} \mathrm{NiSO}_{4}$. Treatments denoted by different lower-case letters are significantly different $(P<0.05)$.

\subsection{Treatment effects}

Alyssum lesbiacum, a well-characterised Ni-hyperaccumulating plant, was grown in $\mathrm{Ni}$ and $\mathrm{PAH}$ co-contaminated soil that was repeatedly amended with different treatments to test individual and combined treatment effects on the phytoextraction of Ni. At the conclusion of the study (14 weeks), treatment SaSoHis-PAH had significantly greater total plant biomass per column $(P=0.0029)$ as compared to treatment SaSoHis (Table 2), indicating a degree of PAH toxicity in $A$. lesbiacum. Treatment SaSoHis also contained $600 \%$ more Ni per unit mass of root than the corresponding treatment SaSoHis-PAH, which might lend some insight into the mechanism of PAH toxicity. Toxicity was most apparent within the first two weeks, when poor seed germination and greater mortality was observed (data not shown). Owing to PAH biodegradation and aging during the study, PAH phytoavailability would have declined rapidly in the early weeks with a concomitant decline in phytotoxicity (White et al., 1998), thereby facilitating the recovery of plant health in PAH-containing treatments. Although toxic effects of PAHs on plant biomass were observed early in the study, this did not significantly impinge on the phytoextraction of Ni per unit mass of shoot (Table 2).

Greater than $90 \%$ of the initial soil PAH spike biodegraded within the 14 week study irrespective of amendment or presence of plant (data not shown). The extensive PAH removal in this study can be attributed to a number of factors, most notably low soil organic matter $(2.24 \%)$ and high coarse soil fraction (77\%), which confer low PAH sorption and high bioavailability 
(Essington, 2004). The similarity between phenanthrene and chrysene chemical structures might have hastened PAH degradation as a single enzyme might be capable of degrading both chemicals. Repeated addition of readily degradable carbon substrates (sorbitan trioleate, salicylic acid and histidine), might provide sufficient nutrients for indigenous microbial population to proliferate and biodegrade the PAHs.

Nickel accumulation in the plant shoot was not enhanced by the exogenous provision of histidine to the soil $(P>0.05$, Table 2 : focused contrast ' 2 vs 5 ' and ' $6 \& 7$ vs. 10 '). This lack of effect might reflect the naturally high concentrations of endogenous histidine in A. lesbiacum, and is consistent with previous research showing no significant increase in $\mathrm{Ni}$ flux into the xylem upon addition of histidine into the rooting medium of hydroponically grown A. lesbiacum (Kerkeb and Krämer, 2003; Krämer et al., 1996). The insensitivity of Ni flux in A. lesbiacum to exogenously supplied histidine contrasts with that of non-hyperaccumulating plants, such as A. montanum and Brassica juncea, which show enhanced $\mathrm{Ni}$ flux into the xylem upon addition of exogenous L-histidine in a hydroponic rooting medium (Kerkeb and Krämer, 2003; Krämer et al., 1996). B. juncea was also shown to be capable of accumulating up to $1.1 \%(\mathrm{w} / \mathrm{w})$ of lead in its shoot tissue dry biomass when exposed to a hydroponic solution of $\mathrm{Pb}$ and EDTA (Vassil et al., 1998). Zea mays also demonstrated a 140-fold increase in lead translocation in the xylem sap after application of an EDTA solution to the soil (Huang et al., 1997). However, unlike hyperaccumulating species, which exhibit a naturally high tolerance to metal concentrations in their shoot biomass of $1 \%(\mathrm{w} / \mathrm{w})$ or greater, nonhyperaccumulator plants rapidly succumb to metal toxicity upon accumulating tissue metal concentrations of this magnitude, necessitating their harvest to ensure that phytoextracted metal is not released onto site through leaf senescence and shedding. The addition of Arthrobacter histidinolovorans in treatment BaSaSoHis did not appear to influence the extent of phytoextracted $\mathrm{Ni}$ per unit biomass of shoot, suggesting that the transfer of $\mathrm{Ni}$ from the soil solution into the plant was not a limiting step under these experimental conditions. As the inoculum was repeatedly amended, we do not think its poor survival in the soil precluded any potential effect.

\subsection{Dynamics of the soil nickel pools}

Soils from both the 0 to $5 \mathrm{~cm}$ and 5 to $10 \mathrm{~cm}$ depths were prepared for $\mathrm{Ni}$ analysis by fractionation into coarse $(>75 \mu \mathrm{m})$ and fine $(<75 \mu \mathrm{m})$ fractions, accounting for approximately $77 \%$ and $23 \%$ of the total soil by mass, respectively. Each soil fraction was assayed for the water-, histidine- and acidextractable Ni pools, representing pools of nickel from which a progressively smaller percentage of nickel is presumed to be phytoaccessible (Table 3 ). Both the fine and coarse fractions of the unspiked study soil contained negligible amounts of water- and histidine-extractable $\mathrm{Ni}$, with $18.40 \pm$ $2.23 \mathrm{mg} \mathrm{Ni} \mathrm{kg}^{-1}$ of the $23.15 \pm 2.21 \mathrm{mg} \mathrm{Ni} \mathrm{kg}^{-1}$ unfractionated soil residing on the coarse fraction. However, roughly all of the Ni spiked into the soil at the outset of the study partitioned into the fine fraction, increasing its acid-extractable $\mathrm{Ni}$ concentration from $20.65 \pm 0.9 \mathrm{mg} \mathrm{Ni} \mathrm{kg}^{-1}$ to $120.95 \pm$ $5.35 \mathrm{mg} \mathrm{Ni} \mathrm{kg}{ }^{-1}$ soil (MSM treatment; $P<0.0001$ ).

\subsection{Phytoextracted nickel pool}

On average, $2297 \pm 955 \mu \mathrm{g} \mathrm{Ni}$ was phytoextracted into the plant biomass per column, accounting for approximately $19 \pm 9 \%$ of the average acid-extractable Ni from the corresponding unplanted control soil (Table 2; $12520 \pm 1239 \mu \mathrm{g}$ $\mathrm{Ni}$ per column). The average percentage $\mathrm{Ni}$ recovery in the plant biomass compares favourably with the results of the study of Li et al. (2003b), in which two other hyperaccumulator species of Alyssum, A. murale and A. corsicum, were shown to phytoextract $11 \%$ of total acid-extractable Ni from Quarry organic soil. Greater percentage recovery of $\mathrm{Ni}$ in this study is likely due to the modest $\mathrm{Ni}$ contamination coupled with the high efficiency of $A$. lesbiacum in phytoextracting $\mathrm{Ni}$ from marginally contaminated soils.

The pool of Ni that is solely histidine-extractable $\left(E_{\mathrm{h}-\mathrm{w}}\right)$ can be defined by subtracting the water-extractable nickel fraction $\left(E_{\mathrm{w}}\right)$ from the total histidine-extractable nickel ( $E_{\mathrm{h}}$; Table 3$)$. Within the 0 to $5 \mathrm{~cm}$ depth, the average $E_{\mathrm{h}-\mathrm{w}}$ pool, $207 \mathrm{mg} \mathrm{Ni}$, was identical in size for both planted and unplanted soils. In the 5 to $10 \mathrm{~cm}$ depth, there was $25 \mu \mathrm{g}$ less $\mathrm{Ni}$ recovered from the planted soil $(189 \mu \mathrm{g} \mathrm{Ni} /$ depth) than the unplanted $\left(214 \mu \mathrm{g} \mathrm{Ni} /\right.$ depth). The $E_{\mathrm{h}-\mathrm{w}}$ pool in the 5 to $10 \mathrm{~cm}$ depth might have been depleted relative to the 0 to $5 \mathrm{~cm}$ depth, as it represents the region with the highest root density (qualitatively assessed, data not shown).

\subsection{Indicator of phytoextractable nickel}

The ratio $\left(E_{\mathrm{r}}\right)$ of $E_{\mathrm{w}^{*}}, E_{\mathrm{h} *}$ and acid-extractable nickel $\left(E_{\mathrm{a}^{*}}\right)$ to the phytoextractable $\mathrm{Ni}\left(E_{\mathrm{p}}\right)$, provides insight into the phytoaccessibility of each of the Ni pools, where the asterisk denotes values from the respective unplanted treatments. The respective unplanted soils were used as a reference for this calculation to account for non-plant treatment effects on $\mathrm{Ni}$ availability. Hence, $E_{\mathrm{r}}$ should equal unity (1.0) when an extractant removes precisely the 'phytoaccessible' $\mathrm{Ni}$ pool.

The average $E_{\mathrm{r}}$ for water-extractable nickel suggests that $E_{\mathrm{w} *}$ greatly underestimates the $E_{\mathrm{p}}$, with an $E_{\mathrm{r}}$ of $2.44 \pm 0.95$ (Fig. 3A), indicating that the average planted soil has at least twice as much $\mathrm{Ni}$ in the plant biomass as can be provided by $E_{\mathrm{w} *} \cdot E_{\mathrm{h} *}$ very closely approximates $E_{\mathrm{p}}$, with an average $E_{\mathrm{r}}$ of $1.14 \pm 0.43$ (Fig. 3A). $E_{\mathrm{r}}$ was slightly greater than unity in a few treatments (i.e., SaSo, SoHis, So, His; Fig. 3B), which might be explained by the following: (1) the plant roots had extended into the pristine soil barrier, enabling the plants to access the additional $2 \mathrm{mg} \mathrm{Ni}$ estimated to be in the pristine soil barrier; and (2) $E_{\mathrm{p}}$ was acquired over a 12 week period from a dynamic, not static, pool of phytoaccessible nickel. A dynamic equilibrium between nickel pools is maintained during the 12 week study as the plant phytoextracts nickel, which is difficult to estimate using an instantaneous method of extracting nickel. Nonetheless, histidine provides a good 

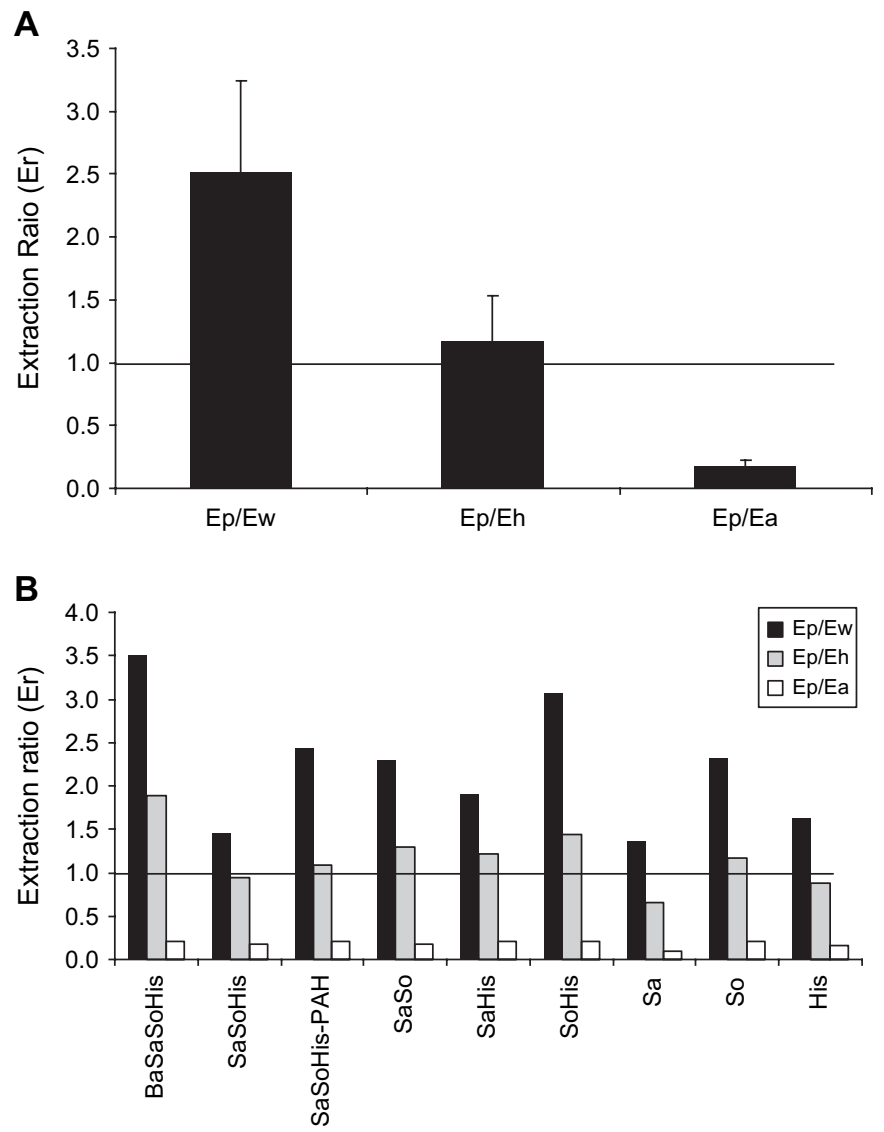

Fig. 3. (A) Average of extraction ratios $\left(E_{\mathrm{r}}\right)$ from all treatments: phytoextracted nickel $\left(E_{\mathrm{p}}\right)$ to water- $\left(E_{\mathrm{w}}\right)$, histidine- $\left(E_{\mathrm{h}}\right)$ and acid- $\left(E_{\mathrm{a}}\right)$ extractable nickel. (B) Average $E_{\mathrm{r}}$ for each treatment, where black, shaded and white columns indicate the $E_{\mathrm{r}}$ for $E_{\mathrm{w}}, E_{\mathrm{h}}$ and $E_{\mathrm{a}}$, respectively.

approximation of the phytoextractable pool for A. lesbiacum. As anticipated, $E_{\mathrm{a}^{*}}$ greatly overestimated $E_{\mathrm{p}}$, with an $E_{\mathrm{r}}$ of $0.19 \pm 0.07$, demonstrating that $A$. lesbiacum had phytoextracted approximately $20 \%$ of $E_{\mathrm{a}^{*}}$ (Fig. 3A). In general, $E_{\mathrm{p}}$ fell within the range achieved in the study of $\mathrm{Li}$ et al. (2003b), in which A. murale phytoextracted upwards of $39 \%$ of the total DTPA-extractable Ni. However, as the authors used DTPA (diethylenetriaminepentaacetate)-extractable nickel as a benchmark for phytoaccessible nickel, and employed a different soil and plant in their study than used in the present work, it is not possible to compare these two studies critically.

\subsubsection{Soil pH effects}

Sulfur and organic acids have previously been shown to enhance metal phytoextraction, possibly in part by lowering soil $\mathrm{pH}$, as well as by ligand-promoted desorption of metals from fixed exchange sites (Kayser et al., 2000; Meers et al., 2004; Robinson et al., 1997a, 1999). However, Li et al. (2003b) observed an increase in Ni uptake by two Alyssum spp. (A. murale and $A$. corsicum) as $\mathrm{pH}$ increased. The authors offered several explanations for this: (1) the plant is better adapted to the phytoextraction of $\mathrm{Ni}$ at higher soil $\mathrm{pH}$; (2) less competition with divalent cations for $\mathrm{Ni}$ uptake at higher $\mathrm{pH}$; (3) increased phytoavailability of organically bound $\mathrm{Ni}$ at higher $\mathrm{pH}$; (4) low binding of Ni to the soil minerals; and (5) more effective binding and uptake of $\mathrm{Ni}$ with histidine at higher soil $\mathrm{pH}$. In our study, the $\mathrm{pH}$ of planted soils was significantly higher than the corresponding unplanted treatments, with average $\mathrm{pH}$ values of $5.61 \pm 0.30$ and $5.75 \pm 0.26$ in planted soils, and $5.19 \pm 0.27$ and $5.45 \pm 0.23$ in unplanted soils, at 0 to $5 \mathrm{~cm}$ and 5 to $10 \mathrm{~cm}$ depths, respectively $(P<0.05$; Table 4$)$. In this study, there was a weak, yet significant, positive correlation between phytoextracted $\mathrm{Ni}$ per column and soil $\mathrm{pH}$ (5 to $10 \mathrm{~cm}$ depth; $\left.R^{2}=0.168 ; F=7.69, P=0.0085, n=36\right)$, thereby lending some support to the findings and hypothetical mechanisms proposed by Li et al. (2003b).

\subsubsection{Bioconcentration factor}

In the present study, $\mathrm{Ni}$ bioconcentration $\left(\mathrm{mg} \mathrm{Ni} \mathrm{kg}^{-1}\right.$ shoot dry biomass/mg $\mathrm{Ni} \mathrm{kg}^{-1}$ acid-extracted unfractionated soil) averaged $50 \pm 13$, which compares positively with an average bioconcentration factor of 60 observed in A. bertolonii growing in natural serpentine soils (Robinson et al., 1997b). Interestingly, the bioconcentration factors were similar between the two investigations, despite the soil used in the $A$. bertolonii study containing a $\mathrm{Ni}$ concentration $\left(1550 \mathrm{mg} \mathrm{Ni} \mathrm{kg}^{-1}\right.$ soil) 32 times greater than in the present study.

\section{Conclusions}

As evident in our study, the hyperaccumulator plant Alyssum lesbiacum can be very effective in phytoextracting $\mathrm{Ni}$

Table 4

Means of soil $\mathrm{pH}$ by depth (mean $\pm \mathrm{SD}, n=4)$ and carbon:nitrogen ratio $(n=2)$

\begin{tabular}{|c|c|c|c|c|}
\hline & & 0 to $5 \mathrm{~cm}$ & 5 to $10 \mathrm{~cm}$ & \\
\hline & & $\mathrm{pH}$ & $\mathrm{pH}$ & $\mathrm{C}: \mathrm{N}$ \\
\hline & & & & $(\% \mathrm{C} / \% \mathrm{~N}$ \\
\hline \multicolumn{5}{|l|}{ Planted } \\
\hline & BaSaSoHis & $5.40 \pm 0.21$ & $5.59 \pm 0.22$ & 11.2 \\
\hline & SaSoHis & $5.46 \pm 0.28$ & $5.43 \pm 0.14$ & 9.4 \\
\hline & SaSoHis-Ni & $5.40 \pm 0.13$ & $5.63 \pm 0.17$ & 11.1 \\
\hline & SaSoHis-PAH & $5.52 \pm 0.09$ & $5.78 \pm 0.16$ & 9.3 \\
\hline & SaSo & $5.64 \pm 0.18$ & $5.88 \pm 0.17$ & 10.1 \\
\hline & SaHis & $5.52 \pm 0.26$ & $5.57 \pm 0.19$ & 9.7 \\
\hline & SoHis & $5.58 \pm 0.32$ & $5.91 \pm 0.17$ & 10.1 \\
\hline & $\mathrm{Sa}$ & $6.15 \pm 0.20$ & $5.91 \pm 0.24$ & 9.7 \\
\hline & So & $5.93 \pm 0.21$ & $6.12 \pm 0.22$ & 11.2 \\
\hline & His & $5.54 \pm 0.32$ & $5.68 \pm 0.13$ & 10.7 \\
\hline \multicolumn{5}{|l|}{ Unplanted } \\
\hline & BaSaSoHis & $5.15 \pm 0.06$ & $5.53 \pm 0.12$ & 11.4 \\
\hline & SaSoHis & $5.06 \pm 0.06$ & $5.23 \pm 0.06$ & 11.5 \\
\hline & SaSoHis-Ni & $4.95 \pm 0.10$ & $5.27 \pm 0.18$ & 11.2 \\
\hline & SaSoHis-PAH & $5.26 \pm 0.13$ & $5.5 \pm 0.09$ & 9.7 \\
\hline & SaSo & $5.50 \pm 0.07$ & $5.64 \pm 0.06$ & 9.5 \\
\hline & SaHis & $5.10 \pm 0.14$ & $5.25 \pm 0.11$ & 8.4 \\
\hline & SoHis & $4.80 \pm 0.07$ & $5.17 \pm 0.09$ & 8.4 \\
\hline & $\mathrm{Sa}$ & $4.99 \pm 0.22$ & $5.51 \pm 0.11$ & 8.3 \\
\hline & So & $5.54 \pm 0.05$ & $5.71 \pm 0.24$ & 10.0 \\
\hline & His & $5.53 \pm 0.07$ & $5.74 \pm 0.09$ & 8.7 \\
\hline & MSM & $5.19 \pm 0.11$ & $5.39 \pm 0.08$ & 8.6 \\
\hline & Pristine & $5.25 \pm 0.10$ & $5.74 \pm 0.22$ & 8.2 \\
\hline
\end{tabular}


from modestly contaminated soils, as well as from soil cocontaminated with phenanthrene and chrysene. Moreover, there was no significant decline in the concentration of nickel in the shoot of A. lesbiacum in the presence of PAHs, suggesting that, within limits, A. lesbiacum might be effective in treating mixed-contaminated soils containing PAHs. This study provides the first demonstration of the application of histidine as an indicator of phytoextractable $\mathrm{Ni}$ from soils. The close agreement between nickel extractability using histidine and nickel phytoaccessibility might have broader implications, since inexpensive assays for the determination of pollutant bioavailability are critically needed for risk assessment, costbenefit analyses and selection of appropriate remediation strategies for contaminated soils.

\section{Acknowledgements}

We thank John C. Day for sequence identification of Arthrobacter histidinolovorans, Martin Wood (University of Reading, UK) for providing the experimental soil, Alan J.M. Baker (University of Melbourne, Australia) for supplying the seeds of Alyssum lesbiacum, and Katja Lehmann, Komang Ralebitso-Senior and Penny Carter for their helpful discussions. This work was supported by the UK Biotechnology and Biological Sciences Research Council through the award of a LINK grant in the Biological Treatment of Soil and Water Programme and by the UK Natural Environment Research Council.

\section{References}

Adams, E., 1954. The enzymatic synthesis of histidine from histidinol. Journal of Biological Chemistry 209, 829-846.

Angle, J.S., Chaney, R.L., Baker, A.J.M., Li, Y., Reeves, R., Volk, V., Roseberg, R., Brewer, E., Burke, S., Nelkin, J., 2001. Developing commercial phytoextraction technologies: practical considerations. South African Journal of Science 97, 619-623.

Arthur, E.L., Rice, P.J., Rice, P.J., Anderson, T.A., Maladi, S.M., Henderson, K.L.D., Coats, J.R., 2005. Phytoremediation - an overview. Critical Reviews in Plant Sciences 24, 109-122.

ATSDR, 1995. Toxicological Profile for Polycyclic Aromatic Hydrocarbons (PAHs), U.S. Department of Health and Human Services. Public Health Service, Atlanta, GA.

Baker, A.J.M., Brooks, R.R., 1989. Terrestrial higher plants which hyperaccumulate metallic elements - a review of their distribution, ecology and phytochemistry. Biorecovery 1, 81-126.

Brooks, R.R., Lee, J., Reeves, R.D., Jaffre, T., 1977. Detection of nickeliferous rocks by analysis of herbarium specimens of indicator plants. Journal of Geochemical Exploration 7, 49-57.

Chen, S.-H., Aitken, M.D., 1999. Salicylate stimulates the degradation of highmolecular weight polycyclic aromatic hydrocarbons by Pseudomonas saccharophila P15. Environmental Science and Technology 33, 435-439.

Environment Agency, 2002. Soil Guideline Values for Nickel Contamination. Department of Environment, Food and Rural Affairs. R\&D Publication CLR7, Bristol, UK.

Essington, M.E., 2004. Soil and Water Chemistry: An Integrative Approach. CRC Press, London.

Freeman, J.L., Garcia, D., Kim, D., Hopf, A., Salt, D.E., 2005. Constitutively elevated salicylic acid signals glutathione-mediated nickel tolerance in Thlaspi nickel hyperaccumulators. Plant Physiology 137, 1082-1091.
Gilbert, E.S., Crowley, D.E., 1997. Plant compounds that induce polychlorinated biphenyl biodegradation by Arthrobacter sp. strain B1B. Applied and Environmental Microbiology 63, 1933-1938.

Huang, J.W., Chen, J., Berti, W.R., Cunningham, S., 1997. Phytoremediation of lead-contaminated soils: role of synthetic chelates in lead phytoextraction. Environmental Science and Technology 31, 800-805.

Ingle, R.A., Mugford, S.T., Rees, J.D., Campbell, M.M., Smith, J.A.C., 2005. Constitutively high expression of the histidine biosynthetic pathway contributes to nickel tolerance in hyperaccumulator plants. The Plant Cell 17, 2089-2106.

Kayser, A., Wenger, K., Keller, A., Attinger, W., Felix, H.R., Gupta, S.K., Schulin, R., 2000. Enhancement of phytoextraction of $\mathrm{Zn}, \mathrm{Cd}$, and $\mathrm{Cu}$ from calcareous soil: the use of NTA and sulfur amendments. Environmental Science and Technology 34, 1778-1783.

Kerkeb, L., Krämer, U., 2003. The role of free histidine in xylem loading of nickel in Alyssum lesbiacum and Brassica juncea. Plant Physiology 131, 716-724.

Khodadoust, A.P., Reddy, K.R., Maturi, K., 2004. Removal of nickel and phenanthrene from kaolin soil using different extractants. Environmental Engineering Science 21, 691-704.

Krämer, U., Cotter-Howells, J.D., Charnock, J.M., Baker, A.J.M., Smith, J.A.C., 1996. Free histidine as a metal chelator in plants that accumulate nickel. Nature 379, 635-638.

Kukier, U., Peters, C.A., Chaney, R.L., Angle, J.S., Roseberg, R.J., 2004. The effect of $\mathrm{pH}$ on metal accumulation in two Alyssum species. Journal of Environmental Quality 33, 2090-2102.

Li, Y.M., Chaney, R., Brewer, E., Roseberg, R., Angle, J.S., Baker, A., Reeves, R., Nelkin, J., 2003a. Development of a technology for commercial phytoextraction of nickel: economic and technical considerations. Plant and Soil 249, 107-115.

Li, Y.M., Chaney, R.L., Brewer, E.P., Angle, J.S., Nelkin, J., 2003b. Phytoextraction of nickel and cobalt by hyperaccumulator Alyssum species grown on nickel-contaminated soils. Environmental Science and Technology 37, $1463-1468$.

McGrath, S.P., Zhao, F.-J., 2003. Phytoextraction of metals and metalloids from contaminated soils. Current Opinion in Biotechnology 14, 277-282.

Meers, E., Hopgood, M., Lesage, E., Vervaeke, P., Tack, F.M.G., Verloo, M.G., 2004. Enhanced phytoextraction: in search of EDTA alternatives. International Journal of Phytoremediation 6, 95-109.

Parker, D.R., Chaney, R.L., Norvell, W.A., 1995. GEOCHEM-PC: A Chemical Speciation Program for IBM and Compatible Personal Computers, Chemical Equilibrium and Reaction Models. Special Publication 42. Soil Science Society of America, Madison, WI.

Robinson, B.H., Brooks, R.R., Howes, A.W., Kirkman, J.H., Gregg, P.E.H., 1997a. The potential of the high-biomass nickel hyperaccumulator Berkheya coddii for phytoremediation and phytomining. Journal of Geochemical Exploration 60, 115-126.

Robinson, B.H., Chiarucci, A., Brooks, R.R., Petit, D., Kirkman, J.H., Gregg, P.E.H., DeDominicis, V., 1997b. The nickel hyperaccumulator plant Alyssum bertolonii as a potential agent for phytoremediation and phytomining of nickel. Journal of Geochemical Exploration 59, 75-86.

Robinson, B.H., Brooks, R.R., Clothier, B.E., 1999. Soil amendments affecting nickel and cobalt uptake by Berkheya coddii: potential use for phytomining and phytoremediation. Annals of Botany 84, 689-694.

Robinson, B., Fernández, J.-E., Madejón, P., Marañón, T., Murillo, J.M., Green, S., Clothier, B., 2003. Phytoextraction: an assessment of biogeochemical and economic viability. Plant and Soil 249, 117-125.

Rosenthal, R., Rosnow, R.L., 1985. Contrast Analysis. Cambridge University Press, Cambridge, Massachusetts.

Schecher, W.D., McAvoy, D.C., 1992. Mineql+- a software environment for chemical-equilibrium modeling. Computers Environment and Urban Systems $16,65-76$

Shaw, L.J., Burns, R.G., 2003. Biodegradation of organic pollutants in the rhizosphere. Advances in Applied Microbiology 53, 1-60.

Singer, A.C., Gilbert, E.S., Luepromchai, E., Crowley, D.E., 2000. Bioremediation of polychlorinated biphenyl-contaminated soil using carvone and surfactant-grown bacteria. Applied Microbiology and Biotechnology 54, 838-843. 
Singer, A.C., Jury, W., Luepromchai, E., Yahng, C.S., Crowley, D.E., 2001. Contribution of earthworms to PCB bioremediation. Soil Biology and Biochemistry $33,765-776$.

Singer, A.C., van der Gast, C.J., Thompson, I.P., 2005. Perspectives and vision for strain selection in bioaugmentation. Trends in Biotechnology 23, 74-77.

van Veen, J.A., van Overbeek, L.S., van Elsas, J.D., 1997. Fate and activity of microorganisms introduced into soil. Microbiology and Molecular Biology Reviews 61, 121-135.
Vassil, A.D., Kapulnik, Y., Raskin, I., Salt, D.E., 1998. The role of EDTA in lead transport and accumulation by Indian mustard. Plant Physiology 117, 447-453.

White, J.C., Quiñones-Rivera, A., Alexander, M., 1998. Effect of wetting and drying on the bioavailability of organic compounds sequestered in soil Environmental Toxicology and Chemistry 17, 2378-2382.

Whitfield, W.A.D., 1974. The Soils of the National Vegetable Research Station, Wellesbourne. Report of the National Vegetable Research Station for 1973. National Vegetable Research Station, Warwick, United Kingdom, pp. 21-30. 